EthnoAnthropoZoom

37.014.5(438):[314.151.3-054.73-53.2:323.281(495.6:=163.3)"1948/1950"

\author{
Anna Kurpiel (Poland) \\ Willy Brandt Centre for German and European Studies \\ University of Wroclaw \\ E-mail:anna.kurpiel@uwr.edu.pl
}

\title{
IDENTITY AND KNOWLEDGE OF MACEDONIAN CHILDREN- REFUGEES IN SOCIALIST POLAND: GEOPOLITICS OF EDUCATION
}

\begin{abstract}
From 1948 till early 1950s, the Polish People's Republic accepted around 15 thousand refugees of the Greek Civil War. The refugees connected with the defeated side of the Greek Communist Army constituted a heterogeneous group of Greeks, Macedonians, and Aromanians, including both adults and children. Poland, like many other Eastern European countries, sheltered them as part of the solidarity within communist parties. However, till 1956 the anti-Yugoslavian discourse affected the fate of refugees in Poland making the refugees of Greek origin a favored group and treating those of Macedonian origin as Tito collaborators.

The paper aims to present the Macedonian schooling system organized in Poland for the refugees together with an unknown case of the Macedonian textbooks for school children prepared and printed in Poland. The analysis of the textbooks is situated in the broader framework of the international policy of the Eastern Block and Yugoslavia, Polish-Macedonian relations in the 20th century as well as the sociology and history of knowledge.
\end{abstract}

Keywords: Macedonians, refugees from the Greek Civil War, sociology of knowledge, education, migrant studies, textbooks

\section{Introduction}

The subject of the article is the transmission of knowledge: both local and formal, of Macedonian children-refugees (mac. deca - begalci) that came to Poland during and after the Greek Civil War. The notions used in the text as well as research questions come from the fields of anthropology, history and sociology of knowledge. The most important aspects are: formal and informal ways of spreading the knowledge, the 
power of knowledge, geopolitics of knowledge and - more general - migrant knowledge in exile. The question of formal knowledge is better developed due to the existence of sources documenting the care and education system organized by Poles for children-refugees. The interesting case outlined in the second part of the article concerns textbooks for Macedonian language, grammar, and culture printed in the Polish People's Republic at the turn of the 1950s and 1960s. Among the eleven textbooks that are available in the Polish National Library are readings, primers, Macedonian grammar books, selections of Macedonian literature and a book of Macedonian folk tales. The Polish State School Publishing House (pol. Państwowe Zakłady Wydawnictw Szkolnych) published all of them. Their creation, what I will explain in the following text, was determined by legitimizing the Macedonian struggle for self-identification.

\section{Macedonian refugees in Poland}

The first 1013 children came by trains via Romania in 1948. In 1949 the next 1000 children arrived in Poland. "Suspicious, distrustful, fearful" - as described in one of the reports. Quasi-militarily trained, ready to escape at the sound of a car. Age: 3 to 14 (Danforth and Boeschoten 2012). Children-refugees from the Greek Civil War (1946-1949), described above, were the first who had to leave the war-torn country. The majority of them were born in the Northern province of Greece - Aegean Macedonia, the region controlled by the Greek Communist Party (KKE) and its Democratic Army. The communist officials decided to relocate them to secure them (official reason) as well as to mobilize their parents (unofficial reason). They asked other "fraternal" communist countries, that time including Yugoslavia, to give the children shelter. All governments concurred. In the spring of 1948, around 15,000 children, accompanied by young women, called in Macedonian Majki - (Eng. "mothers"), and partisans crossed the mountain border with Yugoslavia. From there, they were sent by trains to individual Yugoslav republics, Czechoslovakia, Romania, Hungary, the GDR, and Poland (Danforth and Boeschoten 2012).

One year later, the Greek communists were defeated. Over sixty thousand refugees (partisans and their families) were forced to leave Greece. This time, however, refugees crossed the Greek-Albanian border. Yugoslavia from "brother" became an enemy, as in Tito-Stalin split, Greek communists supported the USSR. Adult refugees got to Poland and USSR (Tashkent) by sea and later to other countries - the GDR, Czechoslovakia, Romania, Hungary. Despite the International Red Cross 
Action of families' reunion, not all the parents reunited with their expelled children.

Poland gave shelter to more than 15 thousands refugees: 7410 Macedonians, 7357 Greeks and 448 Aromanians (Słabig 2008, 314). ${ }^{1}$ More than 3200 thousands of them were children up to 18 years old. ${ }^{2}$

\section{Institutional system of childcare and education in Poland}

Children that came to Poland at the end of 1948 and in 1949 were placed in the so-called State Educational Centers organized for them in the picturesque mountain resorts in Lądek-Zdrój, Solice-Zdrój, DusznikiZdrój and Międzygórze ${ }^{3}$. The centers' task was to "provide good living and health conditions for the children entrusted to them, as well as physical, mental and moral development" (Nakovski 1987, 109). The center in each city consisted of an orphanage, kindergarten, primary school, hospital or preventorium. It was led by a director appointed by the Ministry of Education as well as his deputy and educational council. In total, 40 orphanages were created within the centers, each with approximately 60 pupils divided by age. Although they were subject to the structures of educational centers, each orphanage organized itself internally.

The stay of children-refugees in the mountain resorts did not last long. In 1950, by a decision of the XXII Central Committee of the PZPR and the Main Board of the League of Women, all children were transferred to Zgorzelec, where one institution was created for them. The Zgorzelec State Educational Center (SEC) was located in three building complexes adapted for this purpose. Two of them were located in the former barracks - the so-called "White Barracks" for schoolchildren and "Red Barracks" for the youngest children. The third one, for older youth most often attending vocational schools, was located in the Ujazd district. The "White Barracks" center was named after Nikos Zachariadis while the vocational school in Ujazd was named after Lazo Trpovski, a Macedonian national hero. Children with pulmonary diseases were placed in a sanatorium in Rabka Zdrój. Henryk Orszt became the director of the newly created SEC.

The main task of the new center was to gather all children (over 3200) and provide them with the right conditions for life, development

\footnotetext{
1 Data from 1955.

2 According to Petre Nakovski 1545 children were of Macedonian and 1472 of Greek origin (Nakovski 1987, 109).

3 The centers were financed by the Ministry of Education, Ministry of Health and League of Women. Waclaw Kopczyński was responsible for creating and organizing the centers on behalf of the Ministry of Education.
} 
and learning. In formal terms, the organization of the SEC in Zgorzelec did not differ much from the previous centers. The only change, which however, significantly affected the SEC's activity was the demand for close cooperation with the Greek emigration community, the appointment of a deputy director for Greek affairs (Greek origin) and the employment of former DAG soldiers in the center. All these changes shifted the character of the center to quasi-military resulting in conflicts between Polish and Greek educators.

The State Educational Center in Zgorzelec also didn't exist for a long period. It was liquidated at the end of August 1951, and the army once again occupied the former barracks. Children, after summer camps, were transferred to the newly created center in Police near Szczecin and to 10 others in Lower Silesia (mainly to Pracze Odrzańskie, Wojanów, Szklarska Poręba and Legnica).

For many years, Police was the primary educational center for children from Greece. The buildings of the former synthetic gasoline factory were adapted for this purpose. The area of the center, according to Mieczysław Wojecki, covered 130 ha, which housed as many as 130 residential buildings (Wojecki 1989, 37). Until 1954, the center in Police was the principal place of residence of Greek and Macedonian children in Poland. In the years 1954-1958, it operated only on guardianship and educational basis gathering children whose parents had exceptionally difficult living conditions. Polish children had been also admitted to the Police center since 1958.

The most challenging task for Polish teachers and educators was to organize the school, that is repeatedly emphasized in the reports (Kopczyński 2008, 82). Difficulties arose primarily from the national and regional diversity of children (even children of one nationality sometimes did not understand each other due to different dialects). Another factor was the educational deficits of children whose education during World War II and the Greek Civil War was rudimentary. Therefore, the majority of children were divided into classes by age, not by level of knowledge.

What was, however, the most important for the presented article is the fact that children in the SECs were almost entirely separated from both: Polish society and their Macedonian and Greek relatives. The separation from Polish society, especially in the first year of their stay, was the result of the fact that the arrival of children to Poland and other Eastern Bloc countries was subject to a state secret. ${ }^{4}$ On the other hand, a different way of financing the stay of adults and children in Poland forced the separation of these two groups. When the children had the entire stay: food, accommodation, medical care financed from the state budget, adults had to earn their living on they own - in the work-

4 Radio Free Europe accused Greek communists of kidnapping the children. 
places offered to them, such as factories, state agricultural farms, and manufacturing cooperatives.

The fact of separation made children tractable for formation by teachers and educators employed in the SEC, which in turn gave rise to more pitfalls with uprooting at the forefront. Wacław Kopczyński noticed this fact in his report from the SEC: "Generally, our pupils present plastic educational material allowing them to work and be guided. There are great opportunities in this plasticity, but also educational dangers. One of them is the possibility of quick denationalization."(Kopczyński 2008, 90)

\section{Local knowledge}

The danger of uprooting was a result of the interruption of cultural content transmission. One of its elements is the so-called "local knowledge". Many authors underline the importance of local knowledge in both: history or sociology of knowledge and migrant studies (Burke 2016; Lässig 2016). The local knowledge, in opposition to the formal one, is based on experience and direct transmission.

There is little information available about the local or informal knowledge including tradition or beliefs of Macedonian migrants in Poland. For sure, it was transmitted through personal contacts in so-called "Greek clubhouses" that existed in almost every town inhabited by Greek and Macedonian refugees. ${ }^{5}$ When it comes to children, we can assume that they participated in the local Macedonian knowledge in exile to a small extent, including the Macedonian language (in the native form of usage, that is for instance a dialect). For the first period of their stay in Poland, they even could not spend the summer holidays with their parents. Instead, they were going on the school camps or to the countryside to help the farmers in the harvest - in the so-called "social action" (Wojecki 1989). Consequently, Macedonian children swiftly acculturated to the Polish culture transmitted mainly by teachers and educators. This happened especially during the first year of their stay in Poland that was spent in total separation from their parents who were still in Greece. This issue is also mentioned in Wacław Kopczyński's report from Lądek-Zdrój: "The resource of knowledge, however, is limited and the na-

5 Greek clubs existed as part of the Nikos Belojanis Association of Political Refugees from Greece in Poland (the body representing refugees in Poland). The number of club rooms changed as the years went by: in 1961 there were 29 club rooms, in $1965-30$, in $1967-27$, and in 1968 - 33. Archive of the Institute of National Remembrance AIPN BU 1585/22385 - Reports on the financial and accounting review at Nikos Belojanis Association. 
tive language they use is rudimentary, children lack many terms. Breaks in contact with the older Macedonian generation cause this state of affairs" (Kopczyński 2008, 88).

Local knowledge of Macedonian "children-refugees" that were placed in the State Educational Centers was represented and transmitted by Majki. However, many of its aspects were not at all acceptable by the Polish authorities. There are several reasons for this situation, among others, lack of advanced migration studies and reflection about the pluralism of knowledge. However, one of them seems to be the most important - that is the new communist ideology that infected all educational and cultural systems in postwar Poland. Its main guidelines were: scientification and modernization, a secular model of upbringing and folklorization of lived tradition.

In the already mentioned report from the State Educational Centre local knowledge practiced by Majki was perceived as "primitive" whereas Majki themselves were characterized by their "pessimism" as well as "lack of socio-educational plasticity" (Kopczyński 2008, 88). Wacław Kopczyński firmly states that "we cannot tolerate the habits and educational methods of our Majki". Among them he lists: "spitting in the face as an educational method," "beating and armor as an educational method and "sleeping in clothes for nine days as an expression of mourning" (Kopczyński 2008, 88). On the same page, Kopczyński writes about the negative attitude of Majki toward dentists as well as their passive attitude as kindergarten teachers. No positive factor of their existence was mentioned.

Religion was definitely an essential factor of Macedonian local knowledge - but - again - forbidden due to ideological reasons. Kopczyński mentions it not without a regret:

"Children in Macedonia were raised in a religious spirit. (...) Still, the Majki play the role of a transmission belt, through which superstitious religious customs, longings, regrets, and sometimes hostile attitude towards Polish educators for their religious indifference pass."

Polish authorities not only forbade religious practices, replacing them with ideological education but also deprived children of all religious emblems. ${ }^{6}$

The secularization included the new organization of the ritual year. National holidays replaced religious ones, among others Christmas and Easter. The Christmas tree was decorated for the New Year Eve. This day the Soviet equivalent of Santa Claus - Ded Moroz - came to children

6 This practice is told with regret in interviews because crosses or holy pictures were often the only remembrances of the family home. 
with greetings from "dear beloved Comrade Stalin" bringing gifts "from Comrade Bierut." 7

One of the pillars of the educational plan in the State Educational Centers was the so-called "aesthetic education". It included learning songs, dances, playing instruments as well as decorating children's homes and handcraft. However, the "repertoire of songs, dances, decorative motifs" presented by Majki was described as "very primitive" as it comes to all "technique, level and performance." That is why from the first year of their stay in Poland, children were learning Polish folk dances and songs as well as songs from the communist repertoire (e.g. the International). Macedonian elements were partly included but "upheld, raised a higher level”(Kopczyński 2008, 112) that was reworked according to the guidelines of socialist choreographers. ${ }^{8}$

The response of Polish authorities to all those "primitive" behavior of Majki was the Polonization of children. Wacław Kopczyński wrote:

"We do not want to Polonize and at the same time denationalize Macedonians, but we need to Polonize to give children education, to prepare them in the Polish economic and social environment to become future builders of Macedonia. There is no other way. Educational opportunities from the Greek-Macedonian side are none" (Kopczyński 2008: 98).

The process of rapid Polonization is best illustrated by the situation in which the children served as translators between Poles and Macedonians and Greeks when the adult refugees arrived in Poland in 1949. One of them, a young Macedonian, recalls trips to Międzygórze that he and his tutor took:

"[I went to Międzygórze] as a translator. A few: 10 or 12 boys went there because as many as few thousand people came from Greece in that time! These people looked terrible! What they didn't have with them! It's beyond yours ken! They had some

7 Polish National Archives: APSz, 560/15 - Report on the third quarter of Children Hause No. 10 State Educational Centre in Płakowice.

8 This process took place in the whole postwar Poland, where and when the authentic folk art and village lived traditions were unappreciated and replaced by folklorism such as stage ensembles that performed songs and dances inspired by folk ones from different regions. The folk art and craft were supposed to serve the grander idea of the (homogenous) nation whereas the "rural tradition was identified with backwardness and superstition, and modernization and industrialization became the overriding goal of economic policy at the expense of agricultural development." (Kordjak 2016, 13). 
boilers, kettles, some baking stuff made of clay! Some bread, I don't know which type. All this they brought to Poland."

The above-quoted narration shows the growing gap between children and adult refugees. The mocking tone with which a little Macedonian describes the appearance and equipment of adults proves that he has already taken over the perception of Polish teachers and educators and was able to distinguish "primitive" from "civilized". ${ }^{10}$

\section{The power of knowledge}

The question of (forced) Polonization of children brings about another concept connected to the sociology and history of knowledge: a connection between the knowledge and power. This issue became one of the central aspects of many analyses from the field of history of knowledge (Lässig 2016), especially linked with colonialism and postcolonialism. The "tension between knowledge and power" brings the ideas of cultural hierarchies and social inequalities as "central to understanding knowledge as a historical phenomenon” (Lässig 2016, 37).

The Macedonian refugees in Poland, that were, according to my research, in a constant condition of "minority within a minority" (Kurpiel 2015), stayed in a double dependency: from Poles and Greeks. Poles organized their stay in the country, they were primarily responsible for children's education and upbringing, whereas Greeks continued to hold the highest positions in all organizations in exile. The lopsided distribution of power resulted in the unjust distribution of knowledge among refugees from Greece in Poland.

The other crucial aspect that influenced the Macedonians' fate in Poland (and other Eastern European countries) was the post-war geopolitics, the most important of which was the conflict between Tito and Stalin and the exclusion of Yugoslavia from Cominform in 1948. Because both Polish and Greek communist parties belonged to the "USSRblock," Yugoslavia for the first years of the refugees' stay in Poland was presented as the main enemy. Everything connected to Yugoslavia was considered hostile and thus forbidden. It included not only the Macedonian organizations from WWII or the Greek Civil War (NOF, AFZ - that were dissolved), but also Macedonian literary language in which codifi-

9 Interview with Iraklis Popovski, 06.01.2011, Poland.

10 Sociologists of knowledge are increasingly writing about children as translators of migrant culture and their extremely important role in the migrant world as "go-betweens." (Lässig 2016, 30). 
cation Blaže Koneski had important role. For that reason, the Macedonian refugees in exile were proposed with a new language: the so-called "Slavomacedonian." The newspapers, children's textbooks and all documents for Macedonians were written in Slavomacedonian language. A new but politically correct language was, in fact, a mix of Macedonian and Bulgarian written in Bulgarian alphabet. ${ }^{11}$ All news from the Socialist Republic of Macedonia, including those from families, were banned, censored or distorted by political propaganda.

\section{"Identity turn(s)"}

However, Polish teachers and officials did support one type of local knowledge - the sense of national belonging of migrants. Polish teachers and educators very early recognized Macedonians as a separate nation and supported their efforts of self-identification. What is more - being "civilized" or "science-oriented" meant for Poles staying neutral. Furthermore, neutrality brought about a new value to the polarized Greco-Macedonian society of refugees in which national antagonisms influenced both children and parents. Greek officials in exile continued the process of Hellenization of Macedonians: by translating their names and surnames into Greek or blocking the possibility of Macedonian self-organizing in separation from Greek fellows.

The recognition of Macedonians as a separate nation as well as the imperative to stay neutral led to a new situation for Macedonians, especially children. Polish authorities started to treat them as a separate group and provided them with Macedonian schooling system that included courses for children (language, literature, history of the nation) as well as trainings for teachers.

The "identity-turn" of Macedonians in Poland transpired in two waves. The first one took place shortly after their arrival in Poland when Poles noticed the distinct nationality of Macedonians. As we read in the Waclaw Kopczynski report:

"Our pupils in the first months of working with us presented undifferentiated national material. To our interpellations, the Greek management / Roumelotis and Lili Vasos / replied that the majority are Macedonians and the minority are Greeks. Lessons with children were held in Greek, Macedonian teachers taught

11 Bulgaria, that time connected to USSR, was proposed as a solution for those Macedonians who felt bad in Poland and wanted to live in a Balkan state. Many refugees, however, had relatives living in the Yugoslav - "the bad one" - Republic of Macedonia. 
children, even the youngest ones, only in Greek. The surnames and first names of the children and Majki were given only in Greek. Roumelotis and Lili Vasos, (...) deliberately Hellenized children (Kopczyński 2008: 87) (...). The issue of the separate national consciousness of Macedonians did not exist (Kopczyński 2008: 100)."

However, the visitation of the commission from the Ministry of Education changed this state of affairs. As a consequence of its decision, all Macedonian children in Poland should learn their mother tongue Macedonian. Moreover, the school organized in the State Educational Centers had to be trilingual: Polish, Greek and Macedonian (Kopczyński 2008, 100). That was, according to Kopczyński, the beginning of the awakening of national separateness among Macedonians in Poland.

Macedonian language was introduced into the school program for children in Lądek-Zdrój along with Polish and Greek. Simultaneously, the process initiated by one of the educators, Olga Popowska, of restoring Macedonian names of children began. As Kopczyński writes: "Olga, who in those days transformed from Papa to Popowska, began changing names from Greek to Macedonian, now ending mostly with -ski and -cki “ (Kopczy凶ski 2008, 91). That time Christu became (in return) Ristowski, Gagacis - Gagaczowski, Lazar - Lazowski, etc. ${ }^{12}$

Learning Macedonian language was associated with the necessity to educate teaching staff. Teachers were recruited from a group of Macedonian emigrants. At first, the guerrillas themselves or Majka-guardians became teachers, and as soon as in the second half of the 1950s students educated in Poland completed the pedagogical courses and high schools. The first teacher training course took place from July 15 to September 15, 1949 in Solice (Szczawno) Zdrój. The next ones were carried out every year during the summer holidays. In addition to learning Macedonian, Polish and the basics of child psychology and pedagogy, the courses included lectures on the international political situation and "the history of nation" (Nakovski 2008b).

\section{The second turn - the case of Macedonian textbooks}

The second wave of the Macedonian "identity-turn" in Poland was connected to the political changes, namely the Khrushchev Thaw. Its best illustration is the case of Macedonian textbooks that started to be printed in Poland.

12 The question of Macedonian surnames and their Greek or Macedonian form was raised several times, also during meetings of POW employees in Zgorzelec. 
Till 1956, all schoolbooks were published in the already mentioned Slavomacedonian language - artificially created by Greek Communists to distinguish Macedonians from Greece from those living in Yugoslavia. During first years of their stay in Poland, Macedonian children used textbooks sent from Bucharest, where, at the request of the Central Committee of the Communist Party, educational and school aids were printed and sent to all countries of the People's Democracy. From 1955, textbooks for Macedonian children were initially printed at the Polish State School Publishing House: Macedonian grammar (renewal of the 1953 edition of the Nea Ellada publishing house), then the Macedonian primer and post-elementary reading (based on the handbook published by Nea Ellada from 1950) and readings for $2^{\text {nd }}$ and $3^{\text {rd }}$ grades. The Minister of Education commissioned all textbooks and the primer for review. However, the reviewers, who did not know Macedonian language, were not able to assess the quality of books.

Therefore, it was a big surprise for the Polish authorities when, in 1956, at a summer teaching course in Police, Macedonian teachers, emboldened by the events in Poland and the KKE, reported that Slavomacedonian language, which they had been forced to use in exile so far in Poland, had little in common with Macedonian literary language. It caused some confusion in the Ministry of Education, as evidenced in the following letter:

"At the request of the leadership of the Greek Refugee Association in Poland, the Ministry of Education started printing Macedonian textbooks last year (...)

The Ministry of Education, by printing these textbooks, was convinced - under the influence of Greek and Macedonian comrades - that Macedonian books were written in the language used by Macedonians living in Bulgaria and Greece. When editing Macedonian textbooks, the State Schools Publishing House used Macedonian books published in 19471949 by the Central Committee of the KPG in Bucharest.

On a summer course in July this year, Macedonian teachers who so far were not part of the education process of Macedonian children - informed a representative of the Ministry, Inspector Wacław Kopczyński, that the language which Macedonian children learnt in Poland was artificial. Macedonian teachers claimed that Greek comrades created a new Macedonian language in exile in 1947-1949 for political reasons. Among other things, they removed six sounds from the phonetic alphabet and replaced them with three Bulgarian and three Russian ones. There were no Macedonian schools or Macedonian liter- 
ature in Greece or Bulgaria. The literary language of Macedonians was the language of the Republic of Macedonia in Yugoslavia. (...) According to Macedonian teachers, children could not be taught artificial language and denationalized. The teachers asked to suspend the printing of Macedonian textbooks until the Macedonian intelligentsia finally resolved the matter at the Central Committee of the KKE in Bucharest" (Nakouski 2008a).

Given the above, the confused Ministry decided to stop printing the Macedonian primer and textbooks, and instead decided to bring Macedonian textbooks from Yugoslavia to assess their content and language. Kole Simiczijew, Macedonian refugee in Poland and Professor of Slavic studies, made the assessment. Unfortunately, his review indicated that Yugoslav textbooks for Macedonian children in Poland are not suitable. He listed two significant reasons: lexical (some readers were printed in Serbo-Croatian language) and political (many readers concerned the information about Josip Broz Tito and the Yugoslav Federation).

After a negative review of Yugoslav textbooks, the Ministry decided to publish all textbooks anew. The chief editor of the new textbooks, who supervised the work of the State Publishing House, was Pando Papachristu (mac. Šapkarev).

\section{Textbooks' content and its brief analysis}

Two of the textbooks available in the National Library and published by the State School Publishing House before the "language question" was raised by Macedonian teachers had been printed in Slavomacedonian language: Bukvar i prva čitanka (Eng. Primer and first reader) from 1956 (“developed by the editorial team”) and Čitanka za II klas (Eng. Reader for 2nd grade) ("elaborated by editorial team, edited by Pando Papachristu") - also from $1956 .{ }^{13}$ Both textbooks were re-published in Macedonian literary language. The new editions were, respectively: Bukvar i prua čitanka (Eng. Primer and first reader) edited by Pando Šapkarev, 1958 and Čitanka: za II oddelenie (Eng. Reader for $2^{\text {nd }}$ grade) prepared by

13 The third one published in Slavomacedonian was a grammar book: Gramatika na makedonskio ezik : fonetika, morfologia, no editor mentioned, 1956. However, I have decided not to analyze this one due to lack of my competences. Other books I am not analyzing within this paper (for the same reasons) were published in the official Macedonian language: Primeri od makedonska literatura za VII oddelenie, ed. by K. Simiczijew, P. Šapkarew (Papachristu) 1959, Primeri od literatura za srednite Školi, ed. K. Simiczijew, P. Šapkarew, 1964 and Makedonskie Narodni Prikazni, ed. Pando Šapkarev, 1966. 
the editorial team, translated into Macedonian by P. Bandilov and P. Papachristu, edited by Pando Papachristu, 1958.

In Bukvar, the changes were best visible, because it consisted mainly of the alphabet and simple readers corresponding to each letter. Therefore, instead of the hard sign, in the 1958 edition there was the letter J, instead of the Bulgarian й - Macedonian - ז́, instead of Щ - Ḱ, instead of Ю - Љ and finally, in the 1958 version, S letter was added. As far as the lexical differences are concerned, they were rather minor. In 1956 the word dom (Eng. home) appeared - it was changed in 1958 to kukia, while zabavachnitsa was replaced by detska gradina, kvartira (1956) and subsequently by stan (1958).

In both editions of Bukvar, ideological and patriotic content was presented, e.g., a reading about Gotse Delchev and Jane Sandanski as well as the First of May. In the 1958 edition, however, two readers were left out - "Warsaw" and "Five-pointed star" (Mac. Petokratka).

The visual layer of both editions remained unchanged (both were illustrated by a Pole: J. Korolkiewicz). The prevailing theme pivoted around Polish natural and cultural landscape. The exception was the picture on the page 8 presenting elements of the rural landscape of Greece: field, donkey and some plants including vines and figs. (the previous page previously depicted a similar Polish countryside with vegetables popular in Poland: cabbage, potatoes, onions).

As for both editions for the 2nd-grade readers, the differences were primarily in alphabetical notation and - less prominent - lexical. The content of the textbooks and their arrangement remained unchanged. They both contained primarily didactic and moralizing as well as patriotic and ideological readers. In this second category, it is worth mentioning the reading about Lazo Trpovski, the poem A bre, makedonče, the reader "Cyril and Methodius". In the illustration for the text of "New Year's Eve tree" there was Lenin raising children.

As it comes to the content closer to local knowledge, one can mention the reader "My house" starting with the words: "I often remember our home and village - says older brother of Mice. It was small but very pretty". (p. 9). The sentence was followed by the description of the house and the natural landscape (including plants) around it.

Probably because that the textbook from 1958 was just rewritten in the official Macedonian and the resulting need to update the content, the textbook for the second grade was issued anew in 1964. It was already the work of Pando Šapkarev (in this textbook, his surname appears only in the Macedonian version), with the changed layout. Most readers still presented uncomplicated didactic and moralizing material. Readers about the great October Revolution (p. 25) and Lenin (p. 26) were added from the ideological content's perspective. As far as the patriotic content was concerned, there was an extremely interesting read- 
ing "Beautiful is our fatherland" (Mac. Ubava e Naszata tatkovina). We read in it:

"Greek and Macedonian children who live in the USSR and the People's Republics and are now going to the second grade have not yet seen their homeland. They were born here and grew under the care of hospitable nations. But they often hear their parents talking about their homeland, so they also know a lot about it. “

Interestingly, however, the first child mentioned in the text is Kostakis, who often hears about Athens from his parents. Kostakis' parents, born in the "capital of our homeland", tell him about its charms: a pleasant climate without winters and frosts, as well as monuments: the Acropolis and the Pantheon. Marko, whose parents are from the islands, is mentioned as the second child. It is only in the third place that little Macedonians read about Kole, who is a kosturčanec. His parents were born in the Kastoria region, where "they were fighting against German fascists who wanted to conquer their homeland." Nearby are Lerin and Lerisko Pole, where delicious sweet apples and other fruit ripen. Large and tasty fish swim in the Kosturskie lake. The reader ends with a summarizing sentence: "There is no child who would not love his homeland, and our parents fought for it against fascism" and homework: "write what city your parents come from and what you know about it."

Another reader, this time concerning only Aegean Macedonia, is "From Lerin to Solun" (pp. 29-33). It is the story of Vasyl, who was traveling to Solun with his father. A sightseeing tour is the father's tale of passing cities, plants and animals seen from the train window.

In addition to the above readers, the textbook contains standard texts about Gotse Dolchev, Ilinden, Jane Sandanski and Lazo Trpovski. The novelty is the reader of March 25 - "feast of a brotherly nation Greece" (p. 111).

In the textbook for the $3^{\text {rd }}$ grade (Mac. Čitanka: for 3 oddel) prepared by the editorial team, in which foreign texts in Macedonian were translated by P. Bandilov, R. Markozaniov, T. Belczew, P. Šapkarev (Papachristu) and edited by Pando Šapkarev (Papachristu), the layout is slightly different. Poems as well as "Macedonian national songs" occupy much content. There are considerably more texts filled with patriotic overtones (e.g. about the Republic of Krushevo), as well as illustrations depicting rural life in Greece. On the page 32, there is a poem "My village", starting with the words: "There, far on the south". On the page 13, little Macedonians could read the national song Planino Pirin Planino - about Pirin Mountain and on pages 55-56, the reader Partisantska żetva (eng. "Partisan harvest") - about the harvest of 1948, i.e., during the Greek Civil War. 
The reader: "Letter from the sanatorium" on pages 60-62 can be deemed bizarre, especially in an overview of contemporary education. The story begins with a letter that came to a certain family - from the eldest daughter (and sister) - Jordanka, who is in the hospital. Jordanka writes in it that the operation of her sick shorter leg was successful and that she has a new friend from Bucharest, whom she tells about "our village and our homeland." Having read the letter, the mother is crying. When asked by children about the reason for her tears, the mother replies with joy that people living in the Soviet Union and other People's republics have the opportunity to heal and cure - so she is sure about the health of their children. In contrast, "only people who have money are treated in their homeland."

The text shows a clear divergence, causing some consternation: on the one hand, Jordanka, lying in the hospital, tells a friend from Bucharest about the village - probably located in Aegean Macedonia where she wants to invite her in the summer, on the other hand - the family lives in one of the countries of the Eastern Bloc - and values it in some aspects (e.g., healthcare).

In addition to the above readers, the textbook also contains ideological ones emphasizing love for the Soviet Union, such as "Lenin and a child" (pp. 98-99) or "What happened in Glinnik (a village in Poland)" - about the Soviet Army (pp. 101-103) or "a Pioneer" (pp. 153-4). Correspondingly, like in the textbooks for younger classes, much space is occupied by readings about nature, seasons and their charms. This type of content disappears in the readers of older classes.

A textbook for the 4th grade prepared by an editorial team; foreign texts translated into Macedonian by P. Šapkarev (Papachristu), K. Simiczyjew; editor: Pando Šapkarev (Papachristu) is less illustrated, while the readers are longer. Many of them concern what we can call "patriotic geography,": e.g., the poem "Pirin" or the reader "Pirin Mountains," starting with the words "Our mountains are beautiful, Mountain Pirin!". Interestingly, this is one of the first readers about places located outside Aegean Macedonia and Greece, which seems to treat the entire area of divided Macedonia as a homeland. Such interpretations may be implied by questions found in the book: "Do you know where the Pirin Mountains are? And the Aegean Sea? And what do you know about Vardar? ".

Other "patriotic-geographical" readers are "Athens" (pp. 120123) starting with the words: "Who has not heard of Athens, the capital of Greece" and "Kostur," as well as a reader about "the Village of Gumendža" (Greek: Goumenissa). On the page 130, there is a photo of a woman in Macedonian folk costume from Debarsko (around Debar), and on the subsequent page, there is a poem Tatkovina (Eng. "Fatherland") however, it does not specify where the homeland of expelled children exactly is. 
A different and new section, in comparison to previous readings, deals with the history of Macedonians. It begins with the reader about Illyrians and Thracians "Our land before the arrival of the Slavs" (p. 142), then "Macedonian Slavs and Byzantium" (p. 144), several readings about Macedonia under Turkish occupation, a poem about Karposh (p. 150154 ), reader "The Fight against Greek spiritual slavery" (p.155-6), about VMRO (158), Gotse Delchev (p. 160), Ilinden Uprising (166-7), Pitu Guli, Jane Sandanski, Lazo Trpovski, and Vodenica na dedo Gruev on EAM (p. 189). This series ends with readers about local heroes - a few texts about Mirka Ginova ${ }^{14}$, Pando Shiperkov - a DAG fighter (p. 203), Nikos Belojanis, as well as the poem Begalci (Eng. "Refugees"). As in previous textbooks, there are a couple of readers about the Soviet Union (p. 215) and its achievements - e.g., a combine harvester (p. 261).

In a textbook for the 5th grade (ed. Pando Šapkarev, 1964) the character of the texts changes. Although the editor is the same (with his name written only in Macedonian), the textbook ceases to be his work. The content is dominated by translation of texts of well-known (generally or at the time) writers and poets: Maxim Gorky, Leo Tolstoy, Ion Luca Caragiale $^{15}$, Arkadij Gajdar ${ }^{16}$, Alexander Pushkin, Aesop's fairy tales, and even Viktor Hugo. The entire textbook is divided into five thematic areas. The first is entitled "School" and it contains the majority of the translated texts as well as readers about Archimedes and Galileo Galilei or the poem "Moscow."

The second part is entitled "Fatherland". It includes readers such as: "Zagoriczani - the native village of Dimitar Blagoev", "Ohrid and Prespa lakes", "Shar mountain," "Valley of Tempi" (a village, now Tempe in Greek), "Olimp and Kisav", Tatkovino, ti si ako zdravie (eng. "Fatherland, you are like health") by Ivan Cankar ${ }^{17}$ as well as poems by Rajko Žinzifov. 18

The third subsection entitled Narodno Tvoreštvo (eng. folk art) contains folk tales and folk songs. The fourth is titled "Fight" (mac. Borba). It is comprised of readers about hajduk, the king Marko, "Death of Goce Delcev", about Nikola Karev ${ }^{19}$, Illinden uprising and Republic of Krusevo. The title of the last chapter is "Work and labor". It contains readers about people and work, this time without territorial restrictions, e.g., a text about little black Tom - a shoeshine boy.

14 Mirka Ginova (1916-1946) was teacher and later a fighter during World War II and the Greek Civil War. She is the first woman to be shot in Greece for political reasons.

15 Romanian playwright, novelist, poet and journalist

16 Soviet youth writer.

poems

17 Slovenian writer, representative of the Slovenian modernist movement, as well as

18 Poet and translator from Veles.

19 Macedonian Bulgarian revolutionary in Ottoman-ruled Macedonia. 
The State Schools Publishing House published a textbook for the $6^{\text {th }}$ grade twice: in 1958 and 1968. The first one from 1958 prepared by Kole Simichijew, foreign text translated into Macedonian by K. Simijczijew, edited by Pando Šapkarev (Papachristu) could be seen as a textbook for the literature and history of Macedonia, primarily Aegean part. It begins with a poem "Fatherland" (mac. Tatkovina) by Paskal Paskalevski - a Macedonian poet and writer who wrote about Aegean Macedonia. In the entire textbook we can find several of his poems. The readers focus on the development of Macedonian culture and Macedonian history. The textbook starts with the reader "Brothers Cyril and Methodius And Their Cannon" and go chronologically through St. Naum, "Hajduk", "Karposh Uprising", a reader about Solun, Goste Delchev and the Uprising in Smileva. On the page 30, there is a photo of a woman in a national costume from the Drachevo area whereas on the page 48, there is a drawing depicting a typical Macedonian street from Ohrid region. The handbook also contains texts by Greek authors, e.g., Elli Alexiu (p. 71) or Rigas Feraios (74). Interestingly, there is a Macedonian-Polish dictionary added at the end.

Published in 1968, edited by Pando Šapkarev (Papachristu), the second textbook for the $6^{\text {th }}$ grade has an entirely different character. It is a collection of reprints of folk songs, poems and fragments of texts by well-known local poets and writers, including Nikos Kazandzakis ${ }^{20}$ Kole Chashule, ${ }^{21}$ and Grigor Stavrev Prlicev. ${ }^{22}$ The last textbook for 7th and 8th grade was published in 1966. No editor is mentioned, maybe because it contains only the extracts from literature and poetry.

\section{Conclusion}

The "school books - writes Susan Lassig - with their tremendous power to shape young people's understanding of the world, have a decisive role to play in the education of future citizens has been a matter of faith - and controversy - since the nineteenth century. With their aura of objectivity and special relevance, schoolbooks transmit stateapproved and - depending on the political system - socially acceptable knowledge to diverse social groups, including those struggling for recognition and those who mistrust this kind of official knowledge. In periods of social insecurity, especially at times when the established knowledge order has been called into question and new knowledge orders are

\footnotetext{
20 Greek novelist, poet, playwright, translator and thinker.

21 Macedonian novelist, playwright, publicist, revolutionary-warrior, politician and diplomat.

22 Macedonian writer from the Romantic era and an important representative of 19 th century Macedonian literature.
} 
taking shape, schoolbooks become a topic of political debate. Ultimately, such debates center on the question of what knowledge is to be passed along to the younger generation and thereby inscribed in the nation's cultural memory. What lines of explanation and interpretation are to be communicated? How is knowledge relevant for the present and the future to be organized? What values are to be the basis for social cohesion? (Lässig 2016: 41).

The case of Macedonian textbooks printed in Poland constitutes a perfect illustration of Macedonian fate in Poland in general, especially the distribution of knowledge within this group. In the beginning, the books were printed in an artificial Slavomacedonian language, then published anew by Macedonian editors living in Poland, that was possible due to the international and internal changes within the countries of the Eastern Block. ${ }^{23}$

The new textbooks could be seen as a subsequent and important step of the identity-turn of an oppressed minority, that was done thanks to their efforts as well as the favorable attitude of Poles. The new books were printed in the official Macedonian language and contained crucial information about Macedonians, their history, folklore and literature. For sure, they supported patriotic education and thus - the national identity of young Macedonians in exile.

However, the new textbooks were not coherent, probably for political reasons. The picture of the "fatherland" is not clear. Is it the whole of Greece or only the Aegean Macedonia? Or the region of Macedonia divided into three parts? There were a lot of readers about Athens, even though none of the children had been there, but nothing about Skopje - a city where majority of kids' relatives came from. The history of the Macedonian nation is coherent with one presented in the Republic of Macedonia (with important heroes such as Karposh, Gotse Delchev and events: Illinden Uprising, Krushevo Republic). However, some readers are telling about the Greek holidays. This inconsistency does not correspond to the real situation of Macedonians in Poland, for whom, as shown in my earlier research, in the second half of the 1950s, the Socialist Republic of Macedonia was the primary, ideological homeland (Kurpiel 2015). The most significant number of Macedonians from Poland migrated there, encouraged by the possibility of using the Macedonian language and expressing their national identity. Many of them had relatives in Skopje or other cities.

The incoherent content of the textbooks could also be interpreted as the self-censorship of their editors, who - as I mentioned before were in a constant condition of a minority within the minority, staying between Poles and Greeks. Their difficult task was corresponding to the

23 The interesting anthropological and linguistic aspect of the Slavomacedonian language of textbooks is a question of the linguistic view (picture) of the world. However, it cannot be developed here due to the limits of the article. 
complicated fate of Aegean Macedonians, born in Greece, raised in socialist Poland.

What is more, the textbooks were printed too late. Despite the final success the textbooks brought for education of Macedonian children, until the end of the 1950s children had very limited school's support, which was the period marked by the highest demand for education. Many of the textbooks were used by children already born in Poland, whereas children who came from Greece were deprived of them and educated in a highly ideological way. This ultimately led to a high level of Polonization of Macedonian children and an interruption to spreading the local knowledge.

What seems to be the most authentic is the representation of fatherland via nature: mountains, lakes, or plants. This strategy - unfortunately limited - seems to correspond with a real experience of the homeland that exists in the children-refugees' memories about their childhood in the rural areas of Northern Greece.

\section{References}

Burke, Peter. 2016. What Is the History of Knowledge? What Is History? Cambridge, Malden: Polity Press.

Danforth, Loring M., and Riki van Boeschoten. 2012. Children of the Greek Civil War: Refugees and the Politics of Memory. Chicago, London: The University of Chicago Press.

Kopczyński, Wacław. 2008. "Sprawozdanie Dyrektora Naczelnego Państwowego Ośrodka Wychowawczego, Magistra Wacława Kopczyńskiego, Dotyczące Przyjęcia Dzieci z Macedonii Egejskiej." In Macedońscy Uchodźcy w Polsce. Dokumenty 1948-1975, edited by Petre Nakovski, I:70-125. Skopje: Arhiv na Makedonia.

--—. n.d. "Dzieci Macedońskie w Polsce, Rękopis.”

Kordjak, Joanna. 2016. "Polska - Kraj Folkloru?” In Polska- Kraj Folkloru?, by Joanna Kordjak, 11-40. Warszawa: Zacheta-Narodowa Galeria Sztuki.

Kurpiel, Anna. 2015. Cztery nazwiska, dwa imiona: macedońscy uchodźcy wojenni na Dolnym Śląsku. Poznań: Wydawnictwo Nauka i Innowacje. 
Lässig, Simone. 2016. "The History of Knowledge and the Expansion of the Historical Research Agenda." Bulletin of German Historical Institute 59: 2959 .

Nakovski, Petre. 1987. Makedonski Deca vo Polska (1948-1968): Politikološka Studija. Skopje: Mlad borec.

- - , ed. 2008a. "List Do Ministra Oświaty Zawierający Żadanie Przerwania Druku Podręczników Macedońskich, Warszawa 10.08.1956.” In Macedońscy Uchodźcy w Polsce. Dokumenty 1948-1975, II:142-44. Skopje: Archiv na Makedonia.

---, ed. 2008b. "Świadectwo Ukończenia Macedońskiego Kursu Nauczycielskiego w Polsce, 15.09.1949 r." In Macedońscy Uchodźcy w Polsce. Dokumenty 1948-1975, I: 152-54. Skopje: Archiv na Makedonia.

Słabig, Arkadiusz. 2008. Aparat Bezpieczeństwa Wobec Mniejszości Narodowych Na Pomorzu Zachodnim w Latach 1945-1989. Szczecin: Instytut Pamięci Narodowej - Komisja Ścigania Zbrodni przeciwko Narodowi Polskiemu.

Wojecki, Mieczysław. 1989. Uchodźcy polityczni z Grecji w Polsce 1948-1975. Jelenia Góra: Urząd Wojewódzki. 
EthnoAnthropoZoom 